\title{
Small Scale Irrigation Farming Adoption as a Climate-Smart Agriculture Practice and Its Impact on Household Income in Ethiopia. A Review Paper
}

\author{
Ibsa Dawid Mume \\ Oromia Agricultural Research Institute, Agricultural Economics and Climate Smart Agriculture Researcher
}

\begin{abstract}
Small-scale irrigated farming has been offered as a climate-smart agriculture technology to boost production and diversify livelihood scenarios as an option to mitigate climate change and variability. Small-scale irrigation as a climate-smart agriculture strategy is one of the most important adaptation options for increasing agricultural production in rural areas, stabilizing agricultural production and productivity, and mitigating the negative effects of variable or insufficient rainfall. The reviewed literature showed that the adoption of small-scale irrigation farming as a climate-smart agriculture practice has a significant positive influence on farming income. Smallscale irrigation practice increases the adaptive capacity of households by enhancing farm income. Small-scale irrigation users are better off in crop production that enhances household income and enables buffer against climate variability compared with non-users. Small-scale irrigation is an important strategy in reducing risks associated with both rainfall variability production of different crops twice or three times within a year and increasing income of rural farm-households. Farmers' age, distance to market, and formal employment all negatively influence small-scale irrigation adoption. Off-farm employment, irrigation equipment, access to reliable water supplies, and awareness of water conservation practices all positively promote Small-scale irrigation adoption. As a result, governments and other key stakeholders should consider strengthening smallscale irrigated farming in rural families as climate smart agriculture.
\end{abstract}

Keywords: CSA, Small-scale irrigation adoption, household income, livelihood.

DOI: $10.7176 / \mathrm{JESD} / 12-17-02$

Publication date:September $30^{\text {th }} 2021$

\section{Introduction}

Nowadays, climate variability and changes are among the main environmental challenge within the world. The negative implication of global climate change on the agricultural sector is unequivocal, as its consequences affect the livelihoods of particularly smallholder farmers within the tropics (FAO, 2017). The agricultural poor in Sub Sahara Africa (SSA) earn their livelihoods mostly from climate sensitive rain-fed agriculture. Dependence of smallholder farmers in SSA on such climate sensitive, seasonal staple production systems often lead them into facing multiple-scale poverty traps (Burney \& Naylor, 2012). Accordingly, this often makes economies within the region the most vulnerable to climatic variability and changes (Conway et al., 2010).

Adopting improved land and water management practices amongst other sustainable technologies can help smallholder farmers. Adoption of Small-scale irrigation (SSI) is one among the improved water management in agriculture. It is crucial to consider SSI as a normal practice in smallholder agriculture that boosts farm output, adapts to climate change, and helps people achieve household food security and national development goals. Smallholder farmers in SSA benefit greatly from the adoption of SSI farming, especially given the unreliability and insufficiency of rainfall in many areas (FAO, 2013).

Increases in temperature, as well as rainfall variability, make agriculture the most vulnerable to climate change in nations like Ethiopia, where agriculture is fully reliant on rainfall (Tadesse \& Alemayehu, 2017). Climate-smart agriculture (CSA) has recently emerged as a framework to capture the concept that agricultural systems are frequently developed and implemented to simultaneously improve food security. Climate-smart interventions may help to meet household demands, such as improved productivity, adaptation, and mitigation, as well as the country's SDGs (Kiros Hadgu et al., 2019). The usefulness of the newly introduced techniques in assisting farmers in making decisions about adopting Climate-smart agriculture technology, practices, and policies depending on their local resources, contexts, and agro ecology (Westermann et al., 2015; Thornton et al., 2018; Kiros Hadgu et al., 2019).

Furthermore, activities to make agriculture more sustainable are among the most effective ways to help countries adapt to and reduce global climate change, which are important to the goals of climate smart agriculture policies for improving resilience and adaptability in order to achieve the SDGs. To address recurrent droughts and ensure the food security of the country's ever-growing population, production and productivityimproving agricultural technologies using available resources, such as small-scale irrigation, are promoted for their contributions to accelerating income and improving smallholders' livelihoods (Temesgen et al., 2018; Hamda Tulu, 2014). 
Small-scale irrigation allows farmers to cope with the effects of climate change by increasing productivity per unit of land and increasing production volume (FAO, 2014). Adopting small-scale irrigation technologies as part of climate-smart agriculture strategies allows for the cultivation of land that would otherwise be unusable without irrigation, as well as achieving crop production stability by maintaining soil conditions, allowing some water to seep into the soil, and improving the soil to allow for more vegetation cover (Mango et al., 2018). Irrigation is, in general, one of the possible strategies of feeding the world's constantly rising population (Kalkidan et al., 2016).

Therefore, this seminar aims to review the adoption of small-scale irrigation farming as a climate-smart agriculture practice and its contribution to people's livelihoods. More specifically, the seminar aims to review factors that influence smallholder farmers' decisions to adopt small-scale irrigation, and the impact of adoption of small-scale irrigation farming on household incomes.

\section{Literature Review}

\subsection{Definition and Explanation of Relevant Concepts}

\subsubsection{Irrigation}

According to Belay et al. (2010), irrigation is one method of agricultural intensification and plays dominant role in increasing agricultural productivity. Makombe et al. (2017) irrigation is the supply of water to agricultural crops by artificial means, designed to allow farming in arid regions and to offset the effect of drought in semiarid regions and even in areas where total seasonal rainfall is adequate on average.

\subsubsection{Small Scale Irrigation}

Small Scale Irrigation (SSI) defined as the irrigation started, owned, managed and financed by farmers themselves, individually or in a small group in which farmers produce high value horticultural crops and staple crops (Lefore et al., 2019; Otoo et al., 2018). Small-scale irrigation is a form of irrigation on small plots, in which farmers have the controlling influence and must be involved in the design process and decisions and it covering less than 200 hectares.

\subsubsection{Adoption}

Zilberman et al. (2012) defined Adoption as a change in practice or technology used by a community. The decision to use and choose new technologies to acquire and use innovation. The degree of use of new technology in long-run equilibrium when the farmer has full information about the new technology and its potentials (Feder et al., 1985).

\subsubsection{Climate Smart Agriculture}

Climate Smart Agriculture (CSA) is a fundamental approach to address the interlinked challenges of climate related risks, ecological sustainability and food security (Steenwerth et al., 2014; Lipper \& Zilberman et al., 2018). CSA is a method that requires site-specific assessments of the social, economic and environmental conditions to set a global agenda for investments in agricultural research and innovation by linking the agriculture with development and climate change communities (Neufeldt et al., 2013).

\subsection{Status and Development of Irrigation Practice in Ethiopia}

In Ethiopia, irrigation practice is extremely important to sustainable and reliable agricultural developments. The country has abundant land for irrigation (4.5 million hectares), only a fraction of its potential land (5\%) is being utilized (Abdissa et al., 2017). This might be the reason that irrigation contributes only 3\% of the total food production of the country (Adugna et al., 2014). Belay \& Woldeamlak (2013) argue that irrigation practice is critical to poverty alleviation through increased productivity in rural areas to enhance food security and rural livelihoods status and contribute to the economy. Small-scale irrigation farming has recently received significant focus from local governments to enable farmers to cultivate crops twice or more per annum.

Irrigation practices reduce the risk of crop failure resulting from drought. To address this, the government of Ethiopia has been trying to transform the traditional rain-fed agriculture into mechanized irrigated agriculture, through full packages of value addition and postharvest technologies (Adugna et al., 2014; Eshetu \& Cho, 2017). Currently, the government gives high attention to developing the sector to fully its potential by assessing and supporting local farmers to enhance irrigation practices as well as the promotion of modern irrigation practices (Kalkidan \&Tewodros, 2017).

\subsection{The Necessity for Small Scale Irrigation in Ethiopia}

Small-scale irrigation is preferred due to the easy adaptability of the systems to local environmental and socioeconomic conditions and it is the mitigation for environmental degradation and absence of non-farm income in rural. However, more importantly, small-scale irrigation farming has become important due to the recent shift in the development paradigm to 'development from below, a method subsumed under 'sustainable development' (Daniel, 2015). SSI is one means by which agricultural production can be increased to satisfy the growing food demands in Ethiopia. Small-scale irrigation is a key to increase farmers ${ }^{\text {ee }}$ income, household 
employment and defending livelihoods against economic vulnerability by producing higher value crops for sale in markets and to harvest more than once per annum (Jirane \& Abera, 2015; Dereje \& Desale, 2016). On the other hand, it is a means for self-employment in household labor (Temesgen et al., 2018).

\subsection{Adoption of Small Scale Irrigation as adaptation strategy}

Adoption of small-scale irrigation is a viable strategy for increasing production to meet rising food demand, market-oriented production, achieving food security, making food available, and improving the livelihoods of smallholder farmers, while also increasing climate variability and change adaptive capacity (Woldegebrial et al., 2015). Adaptation response of farmers to climate variability and change is various from area to area and among local farmers to maintain food security in the face of agricultural crop production loss exacerbated by climate change (Schipper et al., 2010; Woldeamlak et al., 2015). Irrigation as a climate wise agriculture strategy is one of the most important adaptation options for increasing agricultural productivity in the country's rural areas (Dereje et al., 2011). According to Abebe Tilahun (2019), irrigation users are better off in crop production, which increases household income and allows them to buffer against climate variability, than non-users.

According to Woldegebrial et al., (2015), among research participants of rural families in irrigation, the degree of poverty and food insecurity differs between irrigation users and non-users, with irrigation users having a lower percentage of poor $(20 \%)$ than non-users (30 percent). Irrigation users had a higher adaptive capacity to climate variability and change than non-users, according to these findings. Small-scale irrigation has key role to stabilize agricultural production, productivity and mitigate the negative impacts of variable or insufficient rainfall. It also has potential to increase both yields and cropping intensity (Abdissa et al., 2017; Mango et al., 2018).

\subsection{Impact of Small Scale Irrigation on Livelihood Outcomes}

Small-scale irrigation helps to improve overall livelihoods by increasing income, food security, job opportunities, social needs fulfillment, and poverty reduction. Increased in agricultural production through diversification and intensification of crops grown, increased household income because of on/off/non-farm employment, source of animal feed, improving human health, soil and ecology degradation prevention and asset ownership are a few to mentioned (Kalkidan et al., 2017).

According to (Dereje \& Desale, 2016), small scale irrigation farming has a significant influence on improving farmers' livelihoods across a variety of variables, including crop diversification, enhanced agricultural productivity, household income, employment opportunities, and participation in community decisions.

\subsubsection{Employment Opportunity}

Irrigation has several advantages, but one of the most important is the creation of jobs. Because labor is one of the most important inputs in small-scale irrigated farming, skilled and experienced laborers are critical to success. Family labor is the most common source of labor in both irrigated and non-irrigated areas (Mamo Esayas, 2018). Furthermore, labor demand is typically higher during peak production periods, requiring farmers to recruit additional labor for transplanting, weeding, and harvesting.

Irrigation thus provides seasonal employment for individuals working on nearby farms. When completing irrigation work, hired labor is compensated in cash, in kind, or both. The irrigators are also employed by the irrigation system (Chazovachii, 2012). Beneficiaries have moved from harvesting once a year (during the rainy season) to two or three times a year, and labor efficiency has improved because of irrigation. Similarly, the average labor cost for irrigation users (estimated just for hired labor) is more than double that of non-user families.

There are two forms of additional labor demand caused by irrigation schemes, according to Kinfe Asayehegn et al., (2011). Irrigation schemes necessitate labor for the building and ongoing maintenance of canals, wells, and pumps, among other things. This is expected to be a significant source of income for the poor, particularly landless rural poor or rural households with excess labor or seasonal excess labor. Second, higher farm output due to irrigation increases demand for farm labor both during the main cropping season and throughout subsequent cropping seasons, requiring more workers and extending the work duration.

According to Mamo Esayas (2018) found that the average hour spent on an irrigated farm is much higher than the average hour spent on a rain-fed only farm for all tasks from plowing to thrashing. Small-scale irrigation, according to the author, is not only utilized to increase household livelihood diversification, but it also generates job opportunities for a substantial segment of poor households. Furthermore, another scholar stated that irrigation provides work opportunities in the community and can improve the society's lifestyle and living quality (Getaneh Ayele., 2011).

\subsubsection{Livelihood Improvement}

Small-scale irrigation has multiple effects on rural people's livelihood development (Tucker \& Yirgu, 2010). In this case, an attempt was made to determine whether irrigating farmers were aware of the changes in their way of life. Small-scale irrigation has a favorable influence on food security, asset ownership, and well-being of rural 
farm households, whether directly or indirectly.

Irrigation-based agricultural intensification may be the most effective technique for poverty reduction and the promotion of sustainable rural livelihoods (Eneyew et al., 2014). Because of this specific circumstance, irrigation user households have the chance to diversify their livelihood scenario. Crop intensification, diversity, and market-oriented production, as outlined by (Kidane et al., 2014), make food available and affordable to both the poor and the wealthy.

\subsubsection{Agricultural Production}

Small-scale irrigated farming has been offered as a climate smart agriculture method to reduce climate change and variability, increasing production and diversifying livelihood scenarios as an option. Smallholder farmers can profit from irrigation by increasing yields and productivity while lowering the chance of crop failure. SSI is a critical technique for decreasing risks connected with both rainfall unpredictability and the production of different crops twice or three times a year, as well as enhancing household income.

As the outcome of different studies pointed out that SSI has the positive influence on agriculture production. According to Kalkidan \&Tewodros (2017) pointed out that the average crop yields per hectare from small-scale irrigated land increases 2.5 times higher than the yield produced by rain fed agriculture. According to Getaneh Ayele (2011), the result of study identified that access to irrigation increases the opportunity for crop intensity and diversification, which increase cropping income, increases crop productivity, and stabilize the risk associated with crop. Consistent with this Getacher et al., (2014); Diao et al., (2010) found out that small-scale irrigation farming reduces climate risks, improves crop production and reduces agricultural production's overdependence on rainfall.

\subsection{Impact of Small Scale Irrigation Farming on Household Income}

Several studies have indicated that SSI positively correlated with household income in different parts of Ethiopia. The main impact of SSI for the enhancement of the income of smallholder farmers are increasing the yield of crop and livestock production, change of cropping system to cash crop, introduction of new better yielding crop varieties, and employment generation (Goitom, 2020). The author pointed out that SSI development has a positive impact on income improvement of rural households. This implies that small-scale irrigation has a significant impact on rural household income in rural areas. According to the analysis the income and consumption of participants is better than nonparticipant. The author concluded that households that participate in small-scale irrigation have a better quality of life than those that do not.

According to Gadisa \& Gebrerufael (2021) studies about the impact of SSI on household income in central Ethiopia: Empirical evidences from Walmara district the average treatment effect on the treated (ATT) result revealed that participation in irrigation significantly affected household income, and irrigator households get more gross income of Birr 22,161 than non-irrigators, and this result is statistically significant.

Demsew \& Ermias (2020) found out that the mean total annual income of irrigation users was ETB 44, 739.94, while their non-irrigation income was ETB 30,773.77. The result showed that participating in SSI schemes increased the total income of households significantly. This result was consistent with the findings of the study Agerie (2016), which reported that households with access to irrigation had a mean annual income of ETB 56,166.59, and the average for the non-users was ETB 26,102.44. In line with this other study conducted by Sesen (2013), indicated that, the average income of irrigation users were ETB 4003.21 and their non-irrigation also ETB 797 the average income difference between them was ETB 2720.88, and hence there is influence mean income difference between irrigation users and non-users.

According to Muez (2014) shows that a small-scale irrigation scheme has a positive impact on householdse farm income. The author also indicated that the annual farm income and food consumption expenditure per adult equivalent of the irrigation participants in $2012 / 2013$ were respectively $48.9 \%$ and $36.4 \%$ higher than that of the nonparticipants.

According to (Ayana Anteneh, 2016) Assessing the impact of small-Scale irrigation on household income show that households' participation in irrigation had significant impact on households' annual income. Other thing remaining constant, total annual income of the irrigators would be higher than that of non-irrigators by about 23,546 Birr. Other study by Woldegebrial et al., (2015) also show that income of households from irrigation has accounted for $38 \%$ of total income.

Seid Abdie (2016) 'the study on the impact of small scale irrigation on crop production and income of households, the propensity score matching (PSM) techniques estimation result showed that SSI has positive and significant impacts on the income of households. The average treatment effect (ATT) estimation revealed that, the mean difference of household income of SSI users and non-users is 12630.40 birr. According to Kinfe et al., (2011) shows that, the total income of irrigation user households would be higher by Birr 26,593.60 than households who do not participate in small-scale irrigation farming.

According to (Leta Legesse, 2018) the study on the impact of small scale irrigation on household farm income and asset holding. The author found out that participation in irrigation user has increased annual 
household farm income by 19,474.8 birr for participant households than non-participant households, which were significant at $1 \%$ level. Similarly, it has increased their physical asset holding which is measured in Ethiopian birr valued 27502.4 ETB at 1\% statistically significance level. Hence, the author concluded that small-scale irrigation has positive and significant impact on annual farm income and asset holding of the rural farming households.

\subsection{Factors Influencing Adoption of Small Scale Irrigation Farming}

In order to enhance small scale irrigation for increasing the adaptive capacity to climate variability and change of small household farmers' socioeconomic and institutional factors must considered for farmers' decision to smallscale irrigation adoption. The evidence from different studies show that there are different socio-economic and institutional factories influencing household decision to adopt small-scale irrigation farming practice.

The local institution and the rural infrastructure services can improve the awareness of people regarding irrigation adoption (Woldegebrial et al., 2015). The authors shows that off-farm employment, access to irrigation equipment, access to reliable water sources and awareness of water conservation practices, such as rainwater harvesting have a significant influence on the adoption of small-scale irrigation farming. Other study Mango et al., (2018) implies that off-farm employment, access to irrigation equipment, access to reliable water sources and awareness of water conservation practices are positively influence SSI adoption whereas farmers' age, distance to market and formal employment are negatively influence the adoption.

According to Dillon (2011), Chazovachii (2012) and Fanadzo (2012) found out that there were a statistical significance difference between irrigation user and non-users in farmland size, livestock and education but insignificant difference in household size, age and gender. Other study Woldegebrial et al., (2015) indicates that a statistical significance difference in education status and household size between the irrigation user and nonusers and there is a significant difference in the application of agricultural inputs and improved seed varieties. However, statistically insignificant difference in age, livestock ownership, land holding, adult equivalent household size rural services.

According to Ayana Anteneh (2016) the probit model indicated that owning irrigation land, having pumping motor and dissatisfaction with the existing irrigation schemes are key factors that influence on irrigation adoption. Demsew \& Ermias (2020) the result of binary logistic regression showed that age, family size, total livestock owned, total annual income, size of irrigable land, frequency of training, market information, and marital status were determinant factors that influence on SSI adoption. In line with this Eshetu \& Cho (2017) noted that age of household head, education level, size of the cultivated land, number of oxen, livestock holding, income from livestock and irrigation found to be influencing household decision on irrigation. Moreover, According to Kinfe et al., (2011), farmers who are members of the formal and informal institutions such as water user association (WUA), peasant associations and local leadership, education are factors influenced to participate in small-scale irrigation farming.

\section{Conclusion and Recommendations}

Small-scale irrigated farming, also known as climate-smart agriculture, is one of the most important adaptation techniques for increasing agricultural productivity in the country's rural areas. In comparison to non-users, smallscale irrigation users are better off in crop output, which increases household income and provides a buffer against climatic unpredictability. Small-scale irrigation users have more adaptive capacity to climate variability and change than non-users.

Numerous studies have indicated that small-scale irrigation positively correlated with household income in different parts of Ethiopia. Irrigation users had a higher income than non-irrigation users. Participating in smallscale irrigation farming increased the total income of households significantly, and Small-scale irrigation has a positive and significant impact on the annual farm income of the rural farming households.

Off-farm employment, irrigation equipment, reliable water sources, and awareness of water conservation practices such as rainwater harvesting, as well as farmland size and household size, all have a significant positive impact on SSI farming adoption, whereas household age, distance to market, and formal employment have a negative impact.

Irrigation user households earn more incomes than non-user households, which helps them, adapt to climate change. To help farmers earn more income, all responsible development partners, including the government and non-governmental organizations (NGOs), should promote small-scale irrigation farming across the country as a climate-smart agriculture technology. Small-scale irrigation has the potential to mitigate frequent climate change and variable rainfall, and it is easily adaptable and functional at an individual level, so the government and other entities should promote it. Therefore, policymakers and other relevant stakeholders should give great attention to strength small-scale irrigation farming as climate change adaption at rural households. 


\section{References}

Abdissa Feyra, Tesema Gemechu, and Yirga Chilot. 2017. Impact analysis of small-scale irrigation schemes on household food security the case of Sibu Sire District in Western Oromia, Ethiopia. Irrigation Drainage System Engineering, (6): 1-7.

Abebe Tilahun A. 2019. The Role of Small-Scale Irrigation in Climate Change Adaptation: The Case of East Belesa District, Amhara Region, Ethiopia. MSc Thesis, Hawassa University, Wondogenet, Ethiopia

Adugna Eneyew, Ermias Alemu, Mekonnen Ayana, \& Mihret Dananto. 2014. The role of small-scale irrigation in poverty reduction. Journal of Development and Agricultural Economics, 6(1): 12-21.

Agerie Nega. 2016. Determinants of smallholder rural farm households' participation in small-scale irrigation and its effect on income in North Gonder zone Amahara Regional State, Ethiopia. International Journal of Innovative Research and Development, 5(6): 592-601.

Anwar, A.W. 2014. Impact of Small Scale Irrigation on Household Welfare.

Ayana Anteneh. 2016. Assessing the impact of small-scale irrigation schemes on household income in Bahir Dar Zuria Woreda, Ethiopia. Journal of Economics and Sustainable Development, 7(21): 82-86.

Ayele, G.K., Nicholson, C., Collick, A.S., Tilahun, S.A. and Steenhuis, T.S. 2013. Impact of small-scale irrigation schemes on household income and the likelihood of poverty in the Lake Tana basin of Ethiopia. ILRI.

Balcha, Y. 2013. Prospects of transforming subsistence agriculture into sustainable livelihoods. A case study of the Ribb sub-catchment, Ethiopia. Master thesis, Uppsala University.

Belay K, Samson E, Belayneh B, Degeye G, and Demeksa T, et al. 2010. Income diversification through improved irrigation in Ethiopia influences, constraints and prospects for poverty reduction evidence from $\mathrm{E}$ / Harerghe. Oromia, Ethiopia.

Belay Mehretie and Woldeamlak Bewket. 2013. Traditional Irrigation and Water Management Practices in Highland Ethiopia: Case Study in Dangila Woreda, Irrigation and Drainage, 62: 435- 448.

Burney, J. A., \& Naylor, R. L. 2012. Smallholder Irrigation as a Poverty Alleviation Tool in Sub-Saharan Africa. World Development, 40(1): 110-123, doi:10.1016/j.worlddev.2011.05.007.

Chazovachii B. 2012. The impact of small-scale irrigation schemes on rural livelihoods: the case of Panganai Irrigation Scheme Bikita District Zimbabwe. Journal of Sustainable Development in Africa 14(4): $217-231$.

Conway, G., Waage, J., \& Delaney, S. 2010. Science and Innovation for Development; UK Collaborative on Development Sciences (UKCDS). London.

Daniel, Z. 2015. The impact of irrigation schemes on farmers 'income and livelihoods in the upper east region of Ghana (Doctoral dissertation, Kwame Nkrumah University of Science and Technology).

Demsew Mengistie and Ermias Debie. 2020. Determinants of Small-Scale Irrigation Practices in Geray Irrigation Scheme, Northwest Ethiopia. The Ethiopian Journal of Social Sciences, 6(2): December 2020.

Dereje Bacha, Regassa Namara, Ayalneh Bogale and Abonesh Tesfaye. 2011. Impact of small-scale irrigation on household poverty: empirical evidence from the Ambo district in Ethiopia. Irrigation and Drainage 60(1): 1-10. DOI: $10.1002 /$ ird.550

Dereje Mengistie and Dessale Kidane. 2016."Assessment of the Impact of Small Scale Irrigation on household livelihood improvement at Guba Lafto" International Journal of Business and Economics Research: 4(4): 217-228.

Diao, X.; Hazell, P.; Thurlow, J. The role of agriculture in African development. World Dev. 2010. (38): 13751383. [CrossRef]

Dillon A. 2011. The effect of irrigation on poverty reduction, asset accumulation, and informal insurance: evidence from Northern Mali. World Development 39(12).

Eneyew, A.; Alemu, E.; Ayana, M.; Dananto, M. 2014. The role of small-scale irrigation in poverty reduction. $J$. Dev. Agric. Econ. (6): 12-21.

Eshetu Tefera, \& Cho, Y. 2017. Contribution of small-scale irrigation to households' income and food security: Evidence from Ketar irrigation scheme, Arsi Zone, Oromia Region, Ethiopia. African Journal of Business Management, 11(3): 57-68.

Fan, S., Brzeska, J., Keyzer, M., \& Halsema, A. 2013. From subsistence to profit: transforming smallholder farms. IFPRI: food policy report. USA: International Food Policy Research Institute (IFPRI).

Fanadzo M. 2012. Revitalization of smallholder irrigation schemes for poverty alleviation and household food security in South Africa: a review. African Journal of Agricultural Research 7(13): 1956-1969.

FAO. 2013. Sourcebook on Climate Smart Agriculture, Forestry and Fisheries (Rome, Italy: Food and Agriculture Organization of the United Nations (FAO).

Feder, G., Just, R.E. and Zilberman, D.1985. Adoption of agricultural innovations in developing countries: A survey. Economic development and cultural change 33(2).

Food and Agriculture Organization of the United Nations (FAO). 2017. Climate-smart agriculture sourcebook. Rome, Italy: 
Food and Agriculture Organization of the United Nations (FAO). 2014. FAO success stories on climate-smart agriculture.

Gadisa Muleta and Gebrerufael Girmay. 2021. The impact of small-scale irrigation on household income in central Ethiopia: Empirical evidences from Walmara district. 'International Journal of Agriculture and Biosciences', (June).

Gebregziabher G, Namara RE, Holden S. 2012. Technical efficiency of irrigated and rain-fed smallholder agriculture in Tigray, Ethiopia: a comparative stochastic frontier production function analysis. Quarterly Journal of International Agriculture 51(3): 203-226.

Getacher, T.; Mesfin, A.; Gebre-Egziabher, G. 2014. Adoption and impacts of an irrigation technology: Evidence from household-level data in Tigray, Northern Ethiopia. Univ. J. Agric. Res., (1): 30-34.

Getaneh Ayele. 2011. The impact of selected small-scale irrigation schemes on household income and the likelihood of poverty in the Lake Tana basin of Ethiopia. Cornell University, USA.

Getaneh G. and Belay Z. 2016. Climate Change in Ethiopia Variability, Impact, Mitigation, and Adaptation. Journal of Social Science and Humanities research 2(4): 20.

Goitom G. 2020. The Contribution of Small-Scale Irrigation on the Livelihood of Small Holder Farmers, the Case of Mereb-Leke Woreda, Central Zone, Tigray, Ethiopia

Hadush, H. 2014. Adoption and Impact of micro Irrigation on Household Income: The case of Eastern Tigray (Doctoral dissertation, Mekelle University).

Hamda Tulu. 2014. The Effects of Small-Scale Irrigation on Rural Households 'income: The Case of Adami Tulu Jido Kombolcha District, Oromia Regional State.

Jirane and Abera Ifa. 2015. "Determinants of Use of Small scale Irrigation and its Effect on Household food Security: The case of Bako Tibe Woreda, West Shoa, Ehiopia" Academia Journal of Agricultural Research 3(10): 264-269

Kalkidan Fikirie and Tewodros Mulualem. 2017. Review on the role of small-scale irrigation agriculture on poverty alleviation in Ethiopia. North Asian International Research Journal of Multidisciplinary 3(6): 19.

Kalkidan, F., Yemiru, T. and Ephrem, T. 2016. Gender dynamics in small-scale irrigation agriculture among smallholder farmers in Lumedistrict in the central RV, Ethiopia.

Kalkidan, F., Yemiru, T. and Ephrem, T. 2017. Challenges in women-managed small-scale irrigation practices: the case of Lume district, central rift valley of Ethiopia. World Research Journal of Agricultural Sciences, 3(1): 054-059.

Kidane, D.; Mekonnen, A.; Teketay, D. 2014. Contributions of Tendaho Irrigation Project to the improvement of livelihood of Agro pastoralists in the Lower Awash Basin, Northeastern Ethiopia. Ethiop. J. Res. Innov. Foresight, 6:1-19

Kinfe Asayehegn. 2012. Irrigation versus rain-fed agriculture: Driving for households' income disparity, a study from Central Tigray, Ethiopia. Agricultural Science Research Journal 2(1): 20-29.

Kinfe, A., Chilot, Y. and Sundara, R. 2011. Effect of small-scale irrigation on the income of rural farm households: the case of Laelay Maichew District, C Tigray, Ethiopia. Journal of Stored Products and Postharvest Research, 2(10): 208-215.

Kiros Hadgu, Badege Bishaw, Miyuki I, Emiru B, Aklilu Negussie et al. 2019. Climate-Smart Agriculture: Enhancing Resilient Agricultural Systems, Landscapes, and Livelihoods in Ethiopia and Beyond. Editors. World Agroforestry (ICRAF), Nairobi, Kenya.

Lefore, N., Giordano, M.A., Ringler, C. and Barron, J. 2019. Sustainable and equitable growth in farmer-led irrigation in sub-Saharan Africa: what will it take? Water Alternatives.

Leta Legesse. 2018. Impact of Small-Scale Irrigation on Household Farm Income and Asset Holding: Evidence from Shebedino District, Southern Ethiopia. Journal of Resources Development and Management 43: 1-8.

Lipper, L. and Zilberman, D. 2018. A short history of the evolution of the climate smart agriculture approach and its Links to climate change and sustainable agriculture debates. In Climate Smart Agriculture: 13-30.

Makombe, G., Namara, R.E., Awulachew, S.B., Hagos, F., Ayana, M. and Kanjere, M. 2017. An analysis of the productivity and technical efficiency of smallholder irrigation in Ethiopia. Water SA, 43(1): 48-57.

Mamo Esayas Ambe. 2018. "Determinants of The performance of small scale irrigation in improving household farm income in Hadiya zone, Ethiopia” Journal of Development and Agricultural Economics 9(2):81-62.

Mango, N., Makate, C., Lulseged Tamene, Mponela, P. and Ndengu, G. 2018. Adoption of small-scale irrigation farming as a climate-smart agriculture practice and its influence on household income in the Chinyanja Triangle, Southern Africa. Land 7(2):49.

Muez, H.A. 2014. The Impact of Small-Scale Irrigation on Rural household Food Security. The case of Emba Alaje woreda (Doct dissertation, Mekelle University).

Neufeldt, H., Jahn, M., Campbell, B.M., Beddington, J.R., DeClerck et al. 2013. Beyond climate-smart agriculture: toward safe operating spaces for global food systems. Agriculture \& Food Security 2(1):12.

Nugusse, W.Z. 2013. Impact of food aid on household food security: empirical evidence. African Journal of 
Business and Economic Research, 8(1): 109-125.

Otoo, M., Lefore, N., Schmitter, P., Barron, J. and Gebregziabher, G. 2018. Business model scenarios and suitability: Smallholder solar pump-based irrigation in Ethiopia.

Schipper, L., Liu, W., Krawanchid, D. and Chanthy, S. 2010. Review of climate change adaptation methods and tools. MRC Technical Paper No. 34, Mekong River Commission, Vientiane.

Seid A.M. 2016. The impact of small-scale irrigation on crop production and income of households: the case of north Achefer woreda, Amhara regional state, Ethiopia Journal of Poverty, Investment and Development: Vol.30: 2016

Sesen, H.G. 2013. The Impact of Community Managed Irrigation on Household Income and Poverty Reduction: The Case of Sehartisamre Wereda, Tigray, Ethiopia.

SteenWerth, K.L., Hodson, A.K., Bloom, A.J., Carter, M.R., Cattaneo et al. 2014. Climate-smart agriculture global research agenda: scientific basis for action. Agriculture \& Food Security 3(1):11.

Tadesse Alemu and Alemayehu Mengistu. 2017. Impacts of Climate Change on Food Security and its Adaptation and Mitigation Options in Ethiopia: A Review. Influence of El Niño on Biodiversity, Agriculture, and Food Security 23-24 February 2017 Haramaya University, Ethiopia: 75.

Temesgen Hirko, Mengistu Ketema, and Fekadu Beyen. 2018. Participation in small-scale irrigation practice: The Case of Abay Chomen District of Oromia, Ethiopia. International Journal of Agricultural Economics, 3 (6): 135-144.

Thornton, P.K., Rosenstock, T., Förch, W., Lamanna, C., Bell et al. 2018. A qualitative evaluation of CSA options in mixed crop-livestock systems in developing countries. In: Climate Smart Agriculture. Springer, Cham: 385-423.

Tucker, J.; Yirgu, L. 2010. Small-Scale Irrigation in the Ethiopian Highlands: What Potential for Poverty Reduction and Climate Adaptation: Addis Ababa, Ethiopia.

Westermann, O., Thornton, P.K. and Förchs, W. 2015. Reaching more farmers: innovative approaches to scaling up climate-smart agriculture.

Woldeamlak Bewket, Radeny, M. and Mungai, C. 2015. Agricultural Adaptation and Institutional Responses to Climate Change Vulnerability in Ethiopia. CCAFS Working Paper no. 106. CGIAR Research Program on Climate Change, Agriculture and Food Security (CCAFS). Copenhagen, Denmark.

Woldegebrial Zeweld, Huylenbroeck, G.V., Hidgot, A., Chandrakanth, M.G. and Speelman, S. 2015. Adoption of Small-Scale Irrigation and Its Livelihood Impacts in Northern Ethiopia. Irrigation and Drainage 64(5): 655-668.

Zilberman, D., Zhao, J. and Heiman, A. 2012. Adoption versus adaptation, with emphasis on climate change. Annu. Rev. Resour. Econ.4 (1):27-53. 